\title{
ALOE-EMODIN GLYCOSIDES AMELIORATE GLUCOSE UTILIZATION VIA INSULIN DOWNSTREAM REGULATORS: AN IN VIVO INVESTIGATION
}

\author{
ANAND $\mathbf{S}^{1,2 *}$, SARAVANABABU $\mathrm{C}^{3}$, LAKSHMI BS ${ }^{1}$, MUTHUSAMY VS ${ }^{1}$ \\ ${ }^{1}$ Department of Chemistry, VELTECH, Chennai - 600062, Tamil Nadu, India. ${ }^{2}$ Centre for Biotechnology, Anna University, Chennai - 600025, \\ Tamil Nadu, India. ${ }^{3}$ Department of Pharmacology, JSS University, Mysore, Karnataka, India. Email: anand.singaravelu@gmail.com
}

Received: 17 June 2016, Revised and Accepted: 29 June 2016

\section{ABSTRACT}

Objective: Aloe-emodin glycosides (AEG) isolated from Cassia fistula stimulates glucose transport and glycogen storage through a phosphatidylinositol 3 kinase (PI3K)-dependent mechanism in L6 myotubes and inhibits adipocytes differentiation in 3T3L1 adipocytes was previously reported. This study intended to investigate the insulin mimetic effect of AEG by in vivo method.

Methods: Male Wistar albino rats were randomly allocated into two groups and fed for a period of 3-week. The high-fat diet group animals were injected with a low dose $(35 \mathrm{mg} / \mathrm{kg}$ ) of streptozotocin to induce Type-2 diabetes. The diabetic rats were then treated with low dose: $10 \mathrm{mg} / \mathrm{kg}$ and high dose: $30 \mathrm{mg} / \mathrm{kg}$ for a period of 21-day. A dose-dependent decrease in fasting blood glucose, cholesterol, and triglycerides levels on treatment with AEG. The carbohydrate metabolism in diabetic rats appeared to improve due to regulation in hepatic enzymes such as hexokinase, glucose-6phosphatase, and fructose 1,6-bisphosphatase with a concomitant increase in glycogen content.

Results: AEG decreased lipid peroxidation and improved the antioxidant (enzymatic and nonenzymatic) levels in the liver of diabetic rats. Treatment with AEG $(30 \mathrm{mg} / \mathrm{kg})$ augmented the phosphorylation of insulin downstream regulators such as insulin receptor beta, insulin receptor substrate 1, PI3K, glucose transporter 4, glycogen synthase kinase 3 beta, and peroxisome proliferator activator receptor gamma in the skeletal muscle tissue of the Type-2 diabetic rats compared to vehicle-treated diabetic rats.

Conclusion: The present results suggested that AEG could serve as an interesting candidate in the drug development for the management of diabetes.

Keywords: Aloe-emodin glycoside, Type-2 diabetes, High-fat diet/streptozotocin, Carbohydrate Metabolism, Glycogen, Antioxidant enzyme.

(C) 2016 The Authors. Published by Innovare Academic Sciences Pvt Ltd. This is an open access article under the CC BY license (http://creativecommons. org/licenses/by/4. 0/) DOI: http://dx.doi.org/10.22159/ajpcr.2016.v9s2.13533

\section{INTRODUCTION}

The worldwide prevalence of Type- 2 diabetes is increasing at a staggering rate, and it has been estimated that by the end of the decade, the number of people having Type-2 diabetes will grow to an excess of 320 million [1]. Noninsulin-dependent diabetes mellitus (NIDDM) is characterized by an insensitivity of peripheral tissues to the action of insulin, termed insulin resistance. Many synthetic drugs and several species of plants have been reported with hypoglycemic activity [2]. The biological effectiveness, minimal side effects, and relatively low cost is some of the desired factors toward the herbal drugs [3]. A wide range of animal models available for the study of Type-2 diabetes [4], even though, the pattern of disease establishment and progression is not similar to the clinical symptoms in humans. Thus, there is a continued quest among the investigators toward the establishment of a better animal model for Type-2 diabetes by either adjusting the existing methods or developing newer methodologies or a combination of both for a better understanding of the disorder.

Many studies emphasized that rats fed on high-fat diet (HFD) develop insulin resistance but neither hyperglycemia nor diabetes [5] and thus, HFD might be a better way to initiate insulin resistance. Streptozotocin (STZ) is widely used to induce both insulin-dependent and NIDDM by inducing $\beta$-cell death through alkylation of DNA [6]. Earlier reports $[7,8]$ reveal that high-fat fed diet in combination with low dose of STZ induced (35 mg/kg body weight [b.wt.]) diabetic model shows similar metabolic features of insulin resistance mimicking the natural history of the disease.

The glucose uptake potential and associated molecular mechanism of aloe-emodin glycosides (AEG) in L6 myotubes and 3T3L1 adipocytes using in vitro models have been reported earlier [9]. In the present study, we have extended our analysis to investigate the pharmacological effect of AEG on experimental animal models mimicking the pathogenesis, and clinical feature of human Type- 2 diabetes mellitus was investigated by HFD/STZ induced Type-2 diabetes in rats.

\section{METHODS}

Isolation and identification of the compound

The flower of Cassia fistula was collected from Tamil Nadu Medicinal Corporation Limited medicinal garden at Kolli Hills, South India. The plant was authenticated by a taxonomist and the voucher specimen of the plant was preserved in our laboratory (voucher number AUCFME21). The dried, pulverized plant powder of C. fistula (100 g) was extracted successively using different organic solvents in their increasing order of polarity (hexane, ethyl acetate, and methanol) at room temperature. The dried extracts were reconstituted with dimethyl sulfoxide $(1 \mathrm{mg} / \mathrm{ml})$ and serially diluted to prepare logarithmic doses ranging from $1 \mu \mathrm{g} / \mathrm{ml}$ to $1 \mathrm{pg} / \mathrm{ml}$. 2-Deoxy-D-[3H] glucose uptake assay was performed to evaluate the bioactivity and the active extract subjected to solvent-solvent fractionation. The soluble portion of the extract in $60 \%$ methanol was partitioned with hexane, chloroform, and butanol. Butanol soluble fraction $(1 \mathrm{~g})$ was found to be bioactive and hence subjected to methanol washing, yielding $21.2 \mathrm{mg}$ of yellow colored amorphous powder. The active fraction was further purified using high-performance liquid chromatography and the structure elucidated using ${ }^{1} \mathrm{H},{ }^{13} \mathrm{C}$ NMR as described earlier [9].

\section{Animals}

Male Wistar albino rats (160-180 g) procured from the Centre for Animal Health Studies, Tamil Nadu Veterinary and Animal Sciences University, Chennai, India, were used in the study. All the experiments were carried out at Centre for Biotechnology, Anna University, Chennai, India. The rats were housed in polypropylene cages (5-6 rats/cage) and kept at standard laboratory conditions 
of $23 \pm 3^{\circ} \mathrm{C}, 40-65 \%$ relative humidity with $12: 12$ hrs light and dark cycle. The animals were acclimatized to the laboratory conditions for 1 week prior to the commencement of experiments. The rats were fed with standard pellet diet and water ad libitum, prior to the dietary manipulation. All the experimental procedures complied with the ethical norms approved by the Ministry of Social Justices and Empowerment, Government of India and Institutional Animal Ethics Committee (IAEC), Anna University, Chennai, India (IAEC/CBT/Min dt.10.11.09/Protocol No. 1).

\section{Acute toxicity}

Acute oral toxicity was performed following OECD - 423: Acute toxic class method test guidelines. Female Wistar albino rats (150-180 g) were used for the acute oral toxicity study. The test was performed in two stages. In the first experiment, the animals were divided into two groups with three animals each. One group received AEG at $2000 \mathrm{mg} / \mathrm{kg}$, per oral (p.o.) and the other group received $0.5 \%$ carboxymethyl cellulose (CMC) as vehicle control at $10 \mathrm{ml} / \mathrm{kg}$, p.o Following vehicle or AEG administration, the animals were observed intensively for $4 \mathrm{hrs}(0.5,2.0,4.0$, and $6.0 \mathrm{hrs})$ for clinical signs such as abnormal gait, convulsions, dyspnea, defecation, exophthalmos, head twitches, lacrimation, loss of corneal reflex, loss of grasping, loss of righting reflex, and piloerection. Administration of AEG produced severe signs of exophthalmos, increased lacrimation, piloerection, and difficulty in respirations in all the three animals. The experiment was repeated with the next lower dose (i.e., $300 \mathrm{mg} / \mathrm{kg}$ ) as per OECD 423 guideline, with similar groupings. b.wt. were recorded at day 1,2 , 7 , and 14 of the study.

\section{Development of HFD/STZ-induced Type-2 diabetic rats and} experimental design

Experimental animals were allocated into two dietary regimens either normal pellet diet (NPD) or HFD. Following 3 weeks of HFD regimen, STZ (35 mg/kg, i.p.) was administered to the experimental animals. After $72 \mathrm{hrs}$, blood samples were collected through sinoorbital puncture and plasma blood glucose (PG), plasma cholesterol (PC), and plasma triglyceride (PT) were measured. Experimental animals with $P G>250 \mathrm{mg} / \mathrm{dl}$ was selected for the study. The animals were then divided into five groups of six animals each, Group A: Normoglycemic (NPD) - received citrate buffer+vehicle $(0.5 \%$ CMC). Group B: Hyperglycemic (HFD) - received STZ+vehicle $(0.5 \%$ CMC). Group $C$ and D: Rats treated with AEG at a dose of 10 and $30 \mathrm{mg} / \mathrm{kg}$, p.o., respectively. Group E: Rats treated with metformin (MET) $(250 \mathrm{mg} / \mathrm{kg}$, p.o.) served as a reference control. From the study, $\mathrm{AEG}$ at 10 and $30 \mathrm{mg} / \mathrm{kg}$ was found to be an optimal dose based on the blood glucose reduction, b.wt., changes and behavioral parameters and therefore further studies were performed at these doses. The treatment was scheduled for 21 days following induction of diabetes. b.wt., PG, PC, and PT were measured on days $0,7,14$, and 21 of the experiment. On day 21, following blood collection the experimental animals were euthanized to harvest the liver and skeletal muscle and were stored at $-80^{\circ} \mathrm{C}$ until analysis.

\section{Sample collection}

\section{Blood sample}

Blood was collected retro-orbitally from the inner canthus of the eye under light ether anesthesia using capillary tubes (Micro Hematocrit Capillaries, Mucaps). Blood was collected in fresh vials containing sodium fluoride and sodium oxalate as anticoagulant/antiglycolytic agents and plasma was separated in a T8 electric centrifuge (RemiUdyog, New Delhi) at 2000 rpm for 2 minutes. On day 22, i.e., after completion of 21 days of treatment, rats were euthanized, and liver and skeletal muscles were dissected from all the experimental animals and washed with ice-cold normal saline.

\section{Clinical biochemistry}

PG, PC, and PT were measured according to the manufacturer's protocol in a semi-automatic biochemical analyzer (Merck 200, India).

\section{Biochemical estimation of enzyme activities}

\section{Hexokinase activity}

The activity of hexokinase was tested based on the reduction of NAD through coupled reaction with glucose-6-phosphate dehydrogenase as per the method described earlier [10]. The absorbance for reduced NAD was measured at $340 \mathrm{~nm}$.

\section{Glucose-6-phosphatase (G6P) activity}

G6P catalyzes the conversion of glucose-6-phosphate to glucose. This enzyme activity was determined as per the method described earlier with slight modifications [11]. Briefly, G6P was assayed by taking $0.3 \mathrm{ml}$ of buffer followed by the addition of $0.5 \mathrm{ml}$ of $0.01 \mathrm{M}$ glucose6-phosphate as substrate. To the test, $0.2 \mathrm{ml}$ of $10 \%$ homogenate was added and further incubated at $37^{\circ} \mathrm{C}$ for $1 \mathrm{hrs}$. The reaction was immediately arrested by the addition of $10 \%$ trichloroacetic acid (TCA). The control reaction rate was correspondingly assessed by adding $0.2 \mathrm{ml}$ of $10 \%$ homogenate after the arresting step. The precipitate was removed by centrifugation at $3500 \mathrm{rpm}$ for 10 minutes. To $50 \mu \mathrm{l}$ of supernatant, $1075 \mu \mathrm{l}$ of distilled water, $125 \mu \mathrm{l}$ of $2.5 \%$ ammonium molybdate, and $50 \mu \mathrm{l}$ of $0.1 \%$ amino napthol sulfonic acid (ANSA) was added and incubated for 10 minutes at room temperature. The blue color intensity was read at $640 \mathrm{~nm}$ using spectrophotometer against a blank that contained all the reagents except the supernatant. The results are expressed in nmoles of inorganic phosphors (Pi) liberated/ $\mathrm{min} / \mathrm{mg}$ of protein

\section{Fructose 1,6-bisphosphatase (F16BP) activity}

F16BP [12] was assayed by taking $1.2 \mathrm{ml}$ of buffer followed by the addition of $0.1 \mathrm{ml}$ of $0.005 \mathrm{M} \mathrm{F16BP}$ as substrate $250 \mu \mathrm{l}$ of $0.1 \mathrm{M} \mathrm{MgCl}_{2}$, $0.1 \mathrm{ml}$ of $0.1 \mathrm{M} \mathrm{KCl}$, and $0.25 \mathrm{ml}$ of $0.001 \mathrm{M}$ ethylenediaminetetraacetic acid (EDTA). To this test, $0.1 \mathrm{ml}$ of $10 \%$ homogenate was added and incubated at $37^{\circ} \mathrm{C}$ for 15 minutes. The reaction was immediately arrested by the addition of $10 \%$ TCA. The control reaction rate was correspondingly assessed by adding $0.1 \mathrm{ml}$ of $10 \%$ homogenate after the arresting step. The precipitate was removed by centrifugation at $3500 \mathrm{rpm}$ for 10 minutes. To $0.2 \mathrm{ml}$ of supernatant, $0.8 \mathrm{ml}$ of distilled water, $0.5 \mathrm{ml}$ of $2.5 \%$ ammonium molybdate, and $0.2 \mathrm{ml}$ of $0.1 \%$ ANSA was added and incubated for 10 minutes at $37^{\circ} \mathrm{C}$. The intensity of blue color was measured at $640 \mathrm{~nm}$ using spectrophotometer against a blank that contained all the reagents except the supernatant. The results are expressed in nmoles of Pi liberated/minute/mg of protein.

\section{Tissue level of glycogen content}

Glycogen content of liver and skeletal muscle was measured according to earlier established method [13]. Samples were homogenized separately in warm $80 \%$ ethanol at a concentration of $100 \mathrm{mg} / \mathrm{ml}$ and centrifuged at $10,000 \mathrm{rpm}$ for 20 minutes. The residue was collected and allowed to dry over a water bath. To each residue, $5 \mathrm{ml}$ of distilled water and $6 \mathrm{ml}$ of perchloric were added. The extraction was further done at $4^{\circ} \mathrm{C}$ for 20 minutes. The collected extract was centrifuged at $10,000 \mathrm{rpm}$ for 15 minutes and the supernatant collected. From the supernatant, $0.2 \mathrm{ml}$ was transferred to a graduated test tube, and the volume was increased to $1 \mathrm{ml}$ by addition of distilled water. Similarly, a graded glycogen standard was made with a volume of $1 \mathrm{ml}$. To each tube added $4 \mathrm{ml}$ of anthrone reagent and incubated at $95^{\circ} \mathrm{C}$ in a boiling water bath for 10 minutes. The absorbance of the samples was measured at $630 \mathrm{~nm}$ after cooling the tube to room temperature. The amount of glycogen in tissue samples was expressed in microgram of glucose per milligram tissue.

\section{Investigation of oxidative stress markers}

Hepatic antioxidant enzymes superoxide dismutase (SOD) [14], glutathione peroxidase (GPx) [15], and antioxidant reduced glutathione (GSH) content [16] were determined. Thiobarbituric acid reactive substance levels (TBARS) [17] levels were also assessed and compared.

\section{Estimation of SOD}

About $0.5 \mathrm{ml}$ of serum was prepared for the reaction by adding $3 \mathrm{ml}$ of sodium pyrophosphate buffer $(0.025 \mathrm{M}, \mathrm{pH} 8.3), 0.25 \mathrm{ml}$ of PMS 
$(186 \mu \mathrm{M})$, and $0.75 \mathrm{ml}$ of NBT $(300 \mu \mathrm{M}$ in a buffer of $\mathrm{pH}$ 8.3). The reaction was started by addition of $0.75 \mathrm{ml}$ of NADH $(780 \mu \mathrm{M}$ in a buffer of $\mathrm{pH}$ 8.3). After incubation at $30^{\circ} \mathrm{C}$ for $90 \mathrm{~s}$, the reaction was stopped by addition of $2.5 \mathrm{ml}$ glacial acetic acid. Then, the reaction mixture was stirred vigorously and shaken with $20 \mathrm{ml}$ of n-butanol. The mixture was allowed to stand for 10 minutes and centrifuged. $15 \mathrm{ml}$ of $\mathrm{n}$-butanol served as blank. The intensity of the color of the chromogen was read at $560 \mathrm{~nm}$. Enzyme activity (1 unit $)=50 \%$ inhibition $/$ minute. The results were expressed as units/minute/mg protein.

\section{Estimation of GPx}

GPx was assayed by taking $1.0 \mathrm{ml}$ of Tris HCL buffer (0.4 M), 0.4 mM EDTA along with $0.5 \mathrm{ml}$ of sodium azide and $1.0 \mathrm{ml}$ of enzyme preparation (hemolysate) and mixed well. Thereafter, $0.5 \mathrm{ml}$ of GSH solution ( $2 \mathrm{mM}$ ) followed by $0.1 \mathrm{ml} \mathrm{H}_{2} \mathrm{O}_{2}$ were added. The overall reaction was arrested by adding $2.5 \mathrm{ml}$ of $10 \%$ TCA. The precipitate was removed by centrifugation at $4000 \mathrm{rpm}$ for 10 minutes. The absorbance was read at $412 \mathrm{~nm}$ using a spectrophotometer. The nonenzymatic reaction rate was correspondingly assessed by replacing the enzyme sample by buffer. The results were expressed as nmol of GSH consumed/minute/mg protein.

\section{Estimation of TBARS content}

The method involved heating of biological samples with $0.8 \mathrm{ml}$ saline, $0.5 \mathrm{ml}$ of BHT, and $3.5 \mathrm{ml}$ TBA reagent for $2 \mathrm{hrs}$ in a boiling water bath. After cooling, the solution was centrifuged at 2,000 rpm for 10 minutes and the precipitate obtained was removed. The absorbance of the supernatant was determined at $532 \mathrm{~nm}$ using spectrophotometer against a blank that contained all the reagents minus the biological sample. The values were expressed in $\mu \mathrm{g} / \mathrm{g}$ tissue.

\section{Estimation of GSH}

$0.5 \mathrm{ml}$ of serum was added to equal volume of ice-cold 5\% TCA. The precipitate was removed by centrifugation at $4000 \mathrm{rpm}$ for 10 minutes. To $1 \mathrm{ml}$ aliquot of supernatant, $0.5 \mathrm{ml}$ of $0.2 \mathrm{M}$ phosphate buffer, $\mathrm{pH} 8.0$ and $1.0 \mathrm{ml}$ of DTNB (0.6 mM in $0.2 \mathrm{M}$ phosphate buffer, $\mathrm{pH} 8.0$ ) was added and mixed well. The absorbance was read at $412 \mathrm{~nm}$ using a spectrophotometer. The values were expressed in $\mu \mathrm{g} / \mathrm{dl}$ serum.

\section{Tissue processing}

The muscle samples were homogenized in ice-cold homogenizing buffer (1\% IGEPAL, $150 \mathrm{mM} \mathrm{NaCl}, 50 \mathrm{mM}$ tris, pH 7.5, 1 mM EDTA, $1 \mathrm{mM}$ poly methyl sulfonyl fluoride, $21 \mathrm{mg} / \mathrm{ml}$ aprotinin, $10 \mathrm{mg} / \mathrm{ml}$ leupeptin) using a polytron homogenizer [18]. The homogenates were kept at ice temperature for $1 \mathrm{hr}$ and then centrifuged at $14000 \mathrm{rpm}$ at $4^{\circ} \mathrm{C}$ for $1 \mathrm{hr}$, and the protein concentration of the supernatants was determined using Bradford's method. The supernatants were stored at $-80^{\circ} \mathrm{C}$ until used.

Insulin signaling markers in muscles of experimental animals The protein expressions of insulin receptor beta (IR $\beta$ ), insulin receptor substrate 1 (IRS1), phosphatidylinositol 3 kinase (PI3K), Akt/protein kinase B, glucose transporter 4 (GLUT4), glycogen synthase kinase 3 beta (GSK3 $\beta$ ), and peroxisome proliferator activator receptor gamma (PPAR $\gamma$ ) [19] for the skeletal muscle were determined. An aliquot (40 mg) of the supernatant was resuspended with lysis buffer, and the proteins (125 mg) were size-fractionated by 10\% SDS-PAGE. After immunoblotting, the gel was transfer to nitrocellulose membranes and incubated with specific primary antibodies and later with necessary secondary antibody and the blot visualized using a Western blotting detection system.

\section{Statistical analysis}

Statistical analysis was performed using GraphPad Prism, 4.03 (San Diego, US). Data were expressed in mean \pm standard error of the mean. Unpaired Student's t-test was used for analyzing the group mean difference in b.wt., glucose, cholesterol, and triglycerides parameters. One-way analysis of variance followed by Tukey's multiple comparison as post-hoc was used for other biochemical parameters and a $\mathrm{p}<0.05$ was fixed as the statistical significance.

\section{RESULTS}

\section{Isolation of AEG}

AEG was isolated from the methanolic extract of $C$. fistula using bioactivity based screening. Structural characterization using NMR and mass spectrometry revealed the compound to be AEG [9]. The molecular formula of the compound is $\mathrm{C}_{21} \mathrm{H}_{20} \mathrm{O}_{10}$ with a molecular mass of 432 (Fig. 1).

\section{Acute toxicity}

Toxicity studies were performed for AEG. Experiments were carried out on normal healthy female rats, and no mortality was observed in the AEG-treated rats with the behavior of the treated rats also appearing normal. There was no lethality or toxic reaction found for any of the selected doses till the end of the study.

\section{Effect of AEG on PG levels in normal and diabetic rats B.wt.}

The b.wt. was found to drop significantly in STZ-induced diabetic rats in comparison to its control counterpart (non-diabetic) $(p<0.05)$. However, after the administration of the AEG, the weight of the animal recovered to almost the normal level of each animal in different groups as noted on day $0,7,14$, and 21 (Table 1 ).

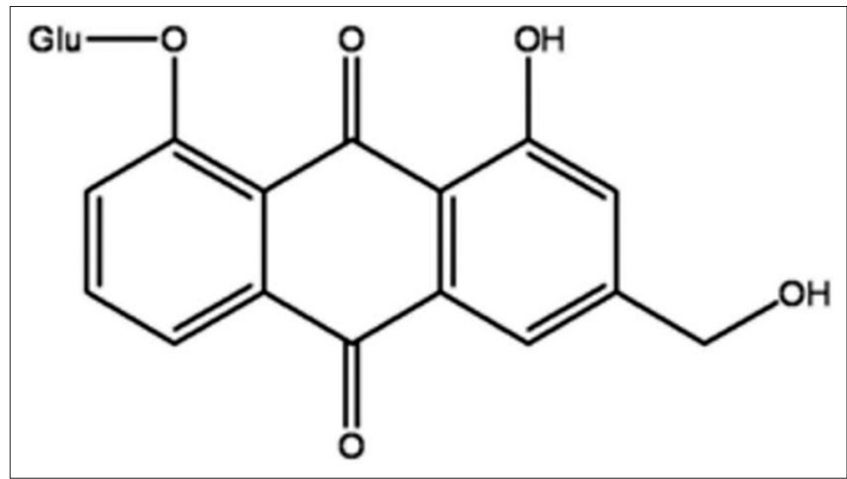

Fig. 1: Structure of the bioactive pure compound chemically characterized as 8-(4, 5-dihydroxy-6 hydroxyl methyl-tetrahydropyran-3yloxy)-1-hydroxy-3-hydroxymethyl- anthraquinone, with molecular formula $\mathrm{C}_{21} \mathrm{H}_{20} \mathrm{O}_{10}$, molecular mass 432 and identified as aloe-emodin glycosides

Table 1: Effect of AEG on body weight

\begin{tabular}{lllll}
\hline \multirow{2}{*}{ Treatment } & \multicolumn{4}{c}{ Body weight (g) } \\
\cline { 2 - 5 } & \multicolumn{1}{c}{$\mathbf{0}$} & $\mathbf{7}$ & $\mathbf{1 4}$ & $\mathbf{2 1}$ \\
\hline Normoglycemic & $163.80 \pm 7.55$ & $173.38 \pm 7.78$ & $185.99 \pm 8.83$ & $192.68 \pm 6.65$ \\
Hyperglycemic & $159.87 \pm 9.61$ & $139.80 \pm 6.98^{\#}$ & $130.77 \pm 9.29^{\#}$ & $129.62 \pm 5.55^{\#}$ \\
Metformin & $164.25 \pm 4.28$ & $171.95 \pm 3.78^{* *}$ & $180.37 \pm 9.36^{* *}$ & $189.24 \pm 5.58^{* *}$ \\
AEG $(10 \mathrm{mg} / \mathrm{kg})$ & $161.60 \pm 7.92$ & $154.80 \pm 6.42$ & $155.76 \pm 6.87$ & $160.22 \pm 8.45$ \\
AEG $(30 \mathrm{mg} / \mathrm{kg})$ & $162.80 \pm 6.35$ & $159.21 \pm 5.82$ & $165.84 \pm 8.22^{*}$ & $178.56 \pm 4.66^{* *}$ \\
\hline
\end{tabular}

Value expressed in mean \pm SEM; $n=6 ;{ }^{\# \notin \&} \mathrm{p}$ value of 0.01 and 0.05 compared to the normoglycemic group, ${ }^{* * \&}$ \& value of 0.01 and 0.05 compared to the hyperglycemic group. AEG: Aloe-emodin glycosides 
Effect of AEG on PG, PC, and PT levels

Dietary manipulation plus low dose of STZ significantly $(\mathrm{p}<0.01)$ elevated PG, PC, and PT levels in the experimental animals. The NPDfed rats appeared normal throughout the experimental period. Table 2 shows the effect of AEG on PG, PC, and PT levels. The biochemical levels were found to be significantly $(\mathrm{p}<0.01)$ high in the hyperglycemic group than in the normoglycemic group on day 0. Oral administration of AEG significantly decreased PG, PC, and PT levels measured on days $0,7,14$, and 21 ( $\mathrm{p}<0.05$ and $\mathrm{p}<0.01$, respectively).

\section{Effect of AEG on key enzymes involved in carbohydrate metabolism} Effect of AEG on hepatic hexokinase activity

The mean value of hepatic hexokinase activity decreased in diabetic rats (Fig. 2a) as compared to the nondiabetic control. The respective percentage decrease was almost $40 \%$ in diabetic controls. Treatment with AEG (30 mg/kg b.wt.) on experimental diabetic rats led to a rise in activity of the enzyme significantly by $50 \%(\mathrm{p}<0.05)$ compared to the diabetic control.

\section{Effect of AEG on G6P and F16BP activity}

Effect of AEG on hepatic G6P and F16BP enzyme in hyperglycemic rats is shown in (Fig. 2b and c) Induction of Type-2 diabetes significantly increased the hepatic G6P and F16BP activity in rats. Oral administration of AEG for 21 days decreased G6P and F16BP activity significantly, and the results were comparable with that of the reference control.

\section{Effect of AEG on glycogen level in tissue}

After 21 days of treatment, the experimental animals were euthanized and the hepatic tissue and the content of skeletal muscle glycogen were determined. A significant decrease in hepatic and skeletal muscle glycogen content was observed compared to vehicle-treated hyperglycemic and normoglycemic rats. Administration of AEG for 21 days increased the glycogen content in liver $(p<0.05)$ and skeletal muscle $(\mathrm{p}<0.01)$ (Fig. 3a and 3b).

\section{Effect on AEG on nonenzymatic antioxidants}

The concentration of glutathione (GSH) content was studied in experimental diabetic rats. During diabetes, a significant decrease in levels of GSH was observed $(\mathrm{p}<0.01)$ compared to the control animals. The diabetic rats treated with AEG and MET showed a significant elevation of the enzyme in the liver tissue compared to the control group (Fig. 4a)

\section{Effect of AEG on enzymatic antioxidants}

The activities of the enzymes SOD and GPx in liver were significantly lowered $(\mathrm{p}<0.05)$ in diabetes rats as compared to normal control rats. The lowered level of antioxidant enzymes was regulated significantly $(p<0.01)$ to normalcy in liver tissue on treatment with AEG in experimental diabetic rats. All the altered enzyme activities are brought back to near normal range $(\mathrm{p}<0.01)$ with MET-treated experimental diabetic rats (Fig. $4 \mathrm{~b}$ and c).

\section{Effect of AEG on TBARS and lipid peroxides}

As seen in Fig. $4 \mathrm{~d}$, there was a significant $(\mathrm{p}<0.05)$ increase in the concentrations of TBARS and lipid peroxides in the liver of diabetic group of rats, compared with those of control group of rats. The concentrations were significantly lower in MET-treated rats. The decreased level of TBARS concentration was also significantly shown in the AEG-treated diabetic rats in comparison to control rats.

\section{Effect of AEG on insulin signaling protein expression in normal and diabetic rats}

The protein expression is shown in (Fig. 5a). There was a significant increase in the phosphorylation of protein such as IR $\beta$, IRS1, PI3K, Akt/ PKB, GLUT4, GSK3 $\beta$, and PPAR $\gamma$ after treatment of AEG. The expressions were quantified using densitometric analysis (Fig. 5b).

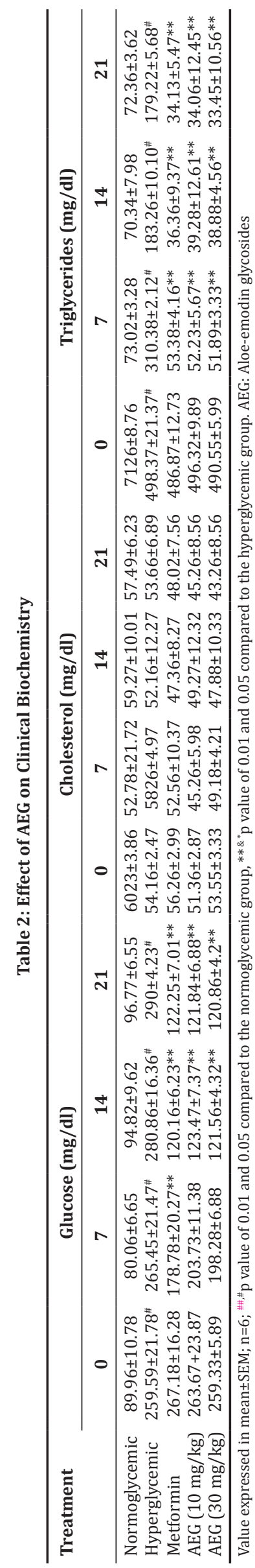




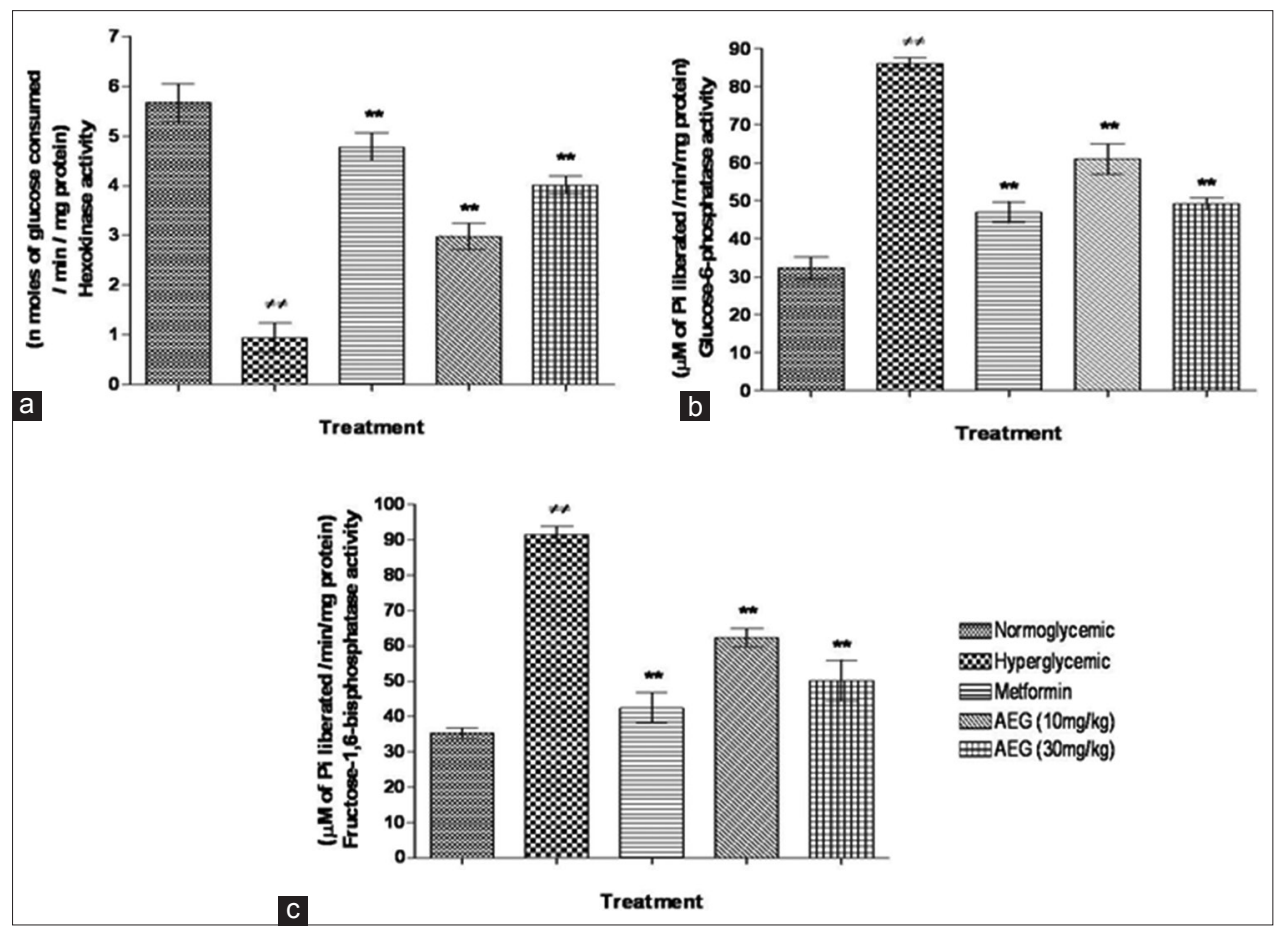

Fig. 2: (a-c) Effect of oral administration of aloe-emodin glycosides on hepatic hexokinase, G6P, and F16BP enzyme levels on normal and streptozotocin-induced diabetic rats. Value expressed in mean \pm standard error of mean; $n=6$; \#\#\&\#p value of 0.01 and 0.05 compared to the normoglycemic group; ${ }^{* *} \& *$ p value of 0.01 and 0.05 compared to the hyperglycemic group

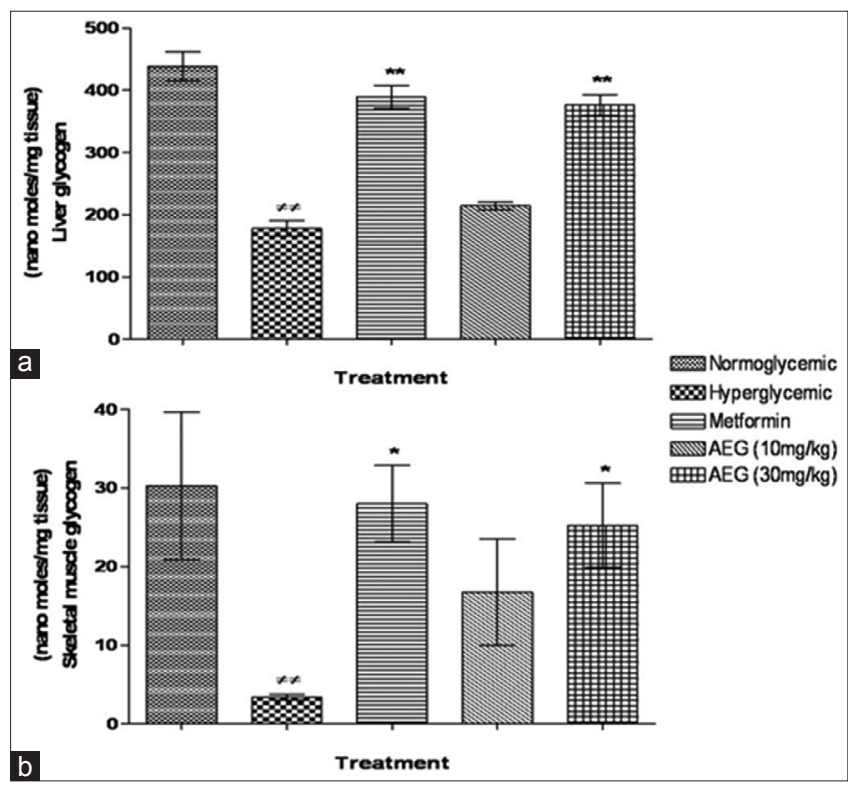

Fig. 3: (a and b) Effect of oral administration of aloe-emodin glycosides on liver and skeletal muscle glycogen content in normal and streptozotocin-induced diabetic rats. Values are expressed in mean \pm standard error of mean; $n=6$; \#\#\& $\&$ value of 0.01 and 0.05 compared to the normoglycemic group; ${ }^{* * \& *}$ p value of 0.01 and 0.05 compared to the hyperglycemic group

\section{DISCUSSION}

Antidiabetic potential of AEG on HFD/STZ-induced diabetic rats Type- 2 diabetes being a complex, heterogeneous, and polygenic disease has many factors underlying it contributing to the high blood glucose levels. A major factor is a resistance of the body to insulin along with decreased secretion of insulin by the $\beta$-cells of the pancreas. Therefore, patients with Type- 2 diabetes may have a combination of deficiency in the secretion and function of insulin. Zhao et al. reported that there was a development of insulin resistance in rats fed with HFD. At the same time, low-dose STZ has been known to induce a mild impairment of insulin secretion which is similar to a feature of the later stage of Type2 diabetes. Qureshi et al. reported [20] the isolation of a small-molecule specifically binding to IR and augmenting the IR-dependent signal transduction cascade that mimics the action of insulin. Enhancement in the insulin sensitivity by small-molecule acting as insulin mimetics has been demonstrated in animal models of Type- 1 and 2 diabetes using in vitro studies [21].

Low and high dose concentration of cinnamon extract have also been observed to increase insulin-regulated glucose utilization via enhancing insulin signaling in male Wistar rats [22]. Hence, the model of HFD and low dose STZ induced Type-2 diabetic model was selected to evaluate the in vivo efficacy of the bioactive compound AEG isolated from $C$. fistula. MET has been used as a reference control to compare the efficacy of AEG. The concentration of AEG in the range of $10 \mathrm{mg} / \mathrm{kg}$ and $30 \mathrm{mg} / \mathrm{kg}$ were selected as the optimum dose for the studies based on previous reports [23].

The present study shows that AEG exhibited a hyperglycemic effect in HFD and low dose STZ-induced diabetic rats when administered orally. The b.wt., of the rats in AEG-treated group was observed to increase after completion of 21 days similar to the reference control. Hence, it can be concluded that AEG does not have any effect on the degradation of fat deposits and maintains the b.wt. in Type- 2 diabetic state. On day 0, an increased level of PG was observed at $259.33 \mathrm{mg} /$ dl. On oral administration of AEG to the experimental rats, on day 21 the levels were observed to decrease to $120.86 \mathrm{mg} / \mathrm{dl}$. Clinically, it has been observed that there is an altered fat metabolism in Type- 1 and Type-2 diabetes leading to altered serum cholesterol and triglyceride levels [24]. Although hypercholesterolemia and hypertriglyceridemia have been reported in STZ induced diabetic rats [25] in insulin-deficient subjects, it fails to activate the enzyme lipoprotein lipase. Hence, in this study, the PC and PT levels were estimated in chronic Type- 2 diabetic rats. AEG-treated rats were observed to lower PC and PT levels $(\mathrm{p}<0.01)$ significantly on day 21 similar to the reference control. 


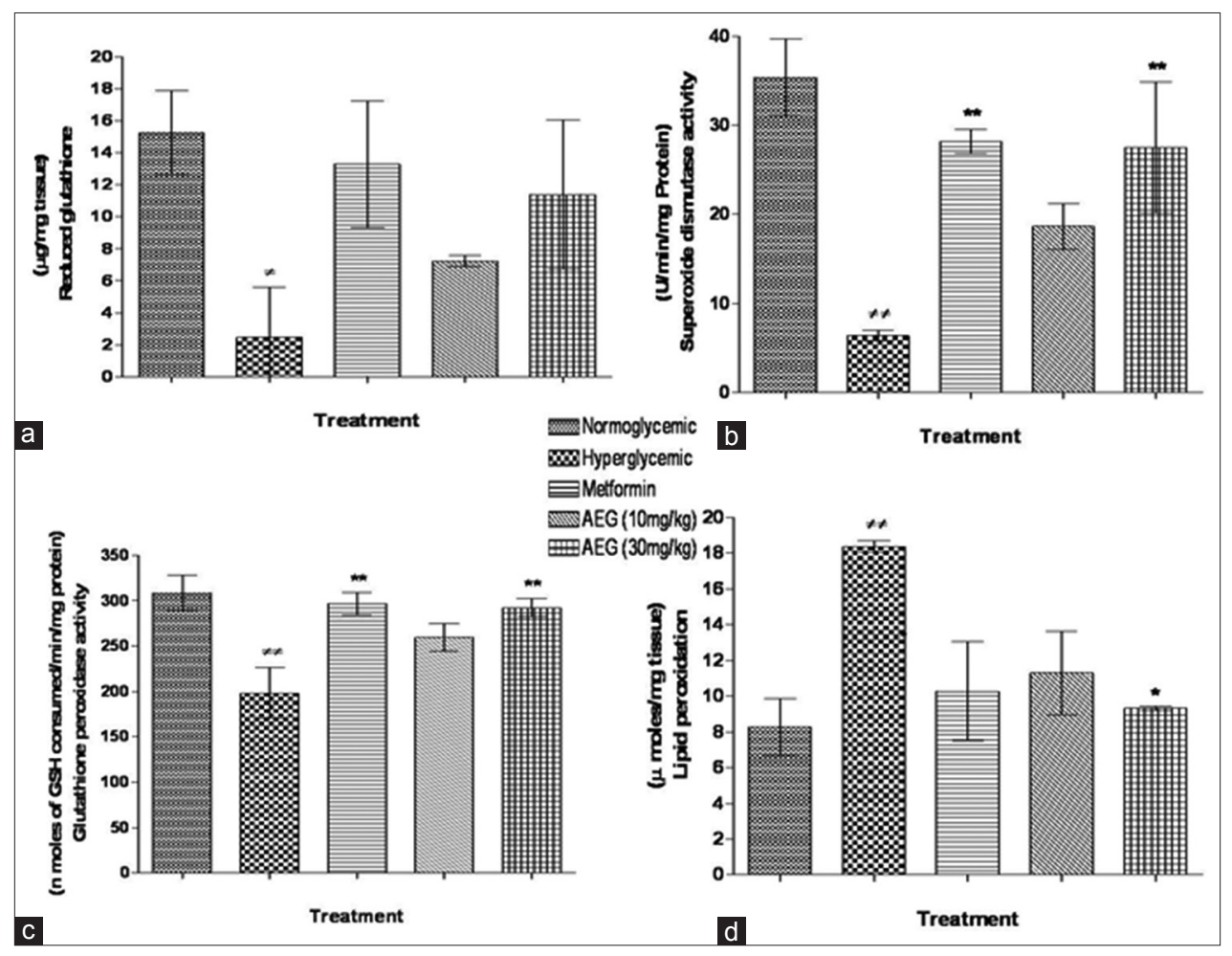

Fig. 4: (a and b) Effect of aloe-emodin glycosides (AEG) on reduced glutathione and superoxide dismutase enzyme levels, (c and d) effect of AEG on glutathione peroxidase and thiobarbituric acid reactive substance. Value expressed in mean \pm standard error of mean; $n=6$; $\# \#, \#$ value of 0.01 and 0.05 compared to the normoglycemic group, $* * * *$ p value of 0.01 and 0.05 compared to the hyperglycemic group

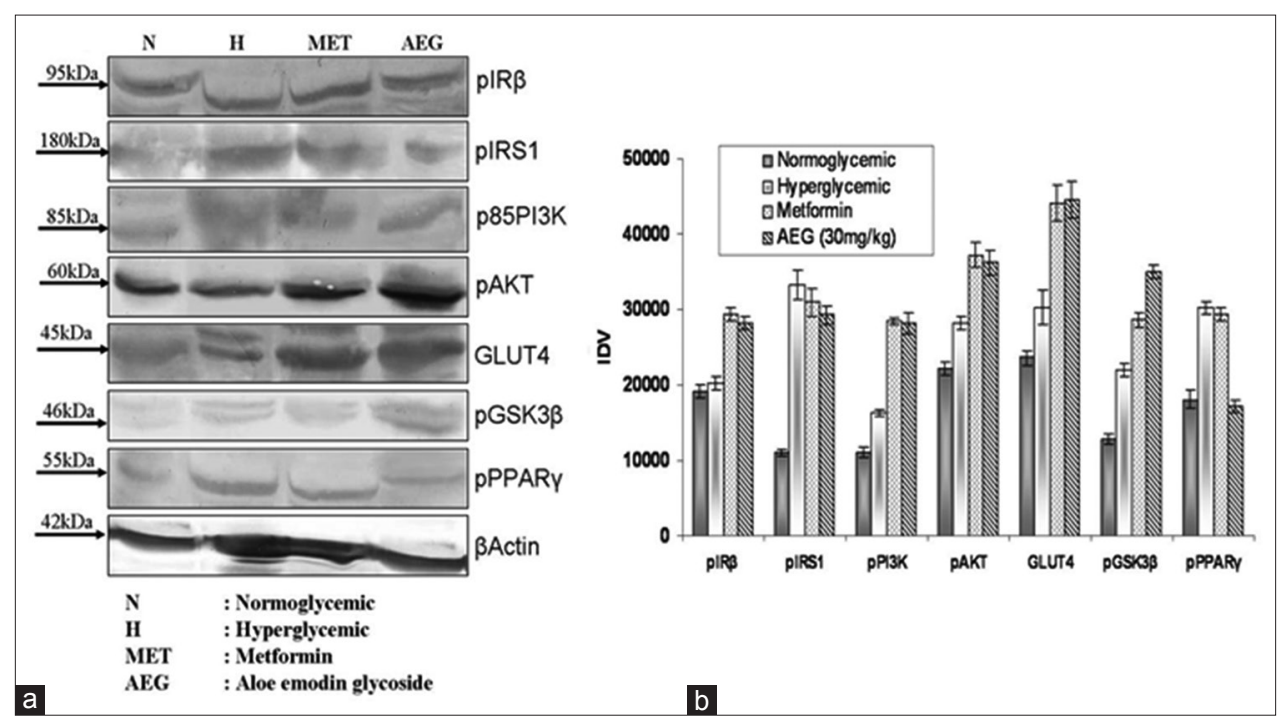

Fig. 5: (a) Effect of AEG on phosphorylation of insulin signaling markers (insulin receptor beta, insulin receptor substrate 1,

phosphatidylinositol 3 kinase, Akt/PKB, glucose transporter 4, glycogen synthase kinase 3 beta, and peroxisome proliferator activator receptor gamma) of skeletal muscles of AEG-treated animals. The protein expressions were normalized by $\beta$-actin expression,

(b) densitometric representation of above insulin signaling markers expressions. Lanes: N: Normoglycemic, H: Hyperglycemic, MET: Metformin, AEG: Aloe-emodin glycosides

\section{Effect of AEG on carbohydrate metabolic enzymes}

The liver is the primary site of endogenous glucose production and produces glucose either from gluconeogenesis or via glycogenolysis. Insulin influences the intracellular utilization of glucose by increasing hepatic glycolysis and the activity of several key enzymes. One such enzyme is hexokinase that catalysis the conversion of glucose to glucose-6-phosphate and plays a central role in the maintenance of glucose homeostasis [26]. Hexokinase is an insulin-dependent enzyme and is almost completely inhibited or inactivated in diabetic rat liver in the absence of insulin [27]. Decreased enzymatic activity of hexokinase has also been reported in diabetic animals, resulting in depletion of liver and muscle glycogen $[28,29]$. To understand the biochemical mechanism of action of AEG, initially, the level of hepatic hexokinase in diabetic rats on treatment with AEG was measured. A reduced level in the activity of hexokinase was observed in STZ-treated diabetic rats whereas treatment with AEG showed an increase in the level of the enzyme to the control level, indicating an overall increase in glucose influx. 
Similarly, G6P has also been reported to play an important role in glucose homeostasis in liver and kidney by activating the gluconeogenic pathway [30]. G6P and F16BP are key enzymes in regulating the gluconeogenic pathway. The activity of G6P and F16BP was found to increase in the liver of diabetic rats [31]. In the current study, it was observed that animals treated with AEG showed an altered gluconeogenesis by inhibiting the activity of G6P and F16BP. An increase in the activity of glucose-6-phosphate dehydrogenase was also observed on treatment with AEG leading to enhanced glucose utilization.

\section{Effect of AEG on glycogen content}

Insulin, a stimulator of glycogen synthase, inhibits glycogenolysis by suppressing glycogen phosphorylase. In the absence or diminished insulin secretion, expression of glycogen synthase will also be lowered leading to a decreased storage of liver glycogen content [32]. Glycogen is the primary intracellular storage form of glucose and its levels in various tissues, especially liver and skeletal muscle are a direct reflection of insulin activity. It has been previously demonstrated that glycogen deposition from glucose is impaired in diabetic animals [33] in proportion to the severity of insulin deficiency [34] due to the damage of Islets of $\beta$-cells caused by STZ. The previous study by [35] showed that tissue glycogen content was reduced drastically in diabetic rats. Treatment of AEG to diabetic rats showed that AEG stimulates increased secretion of insulin, thereby improving the glycogen content of liver. The loss of b.wt. in diabetic control animals may be due to an increased catabolism of glycogen in muscle and liver, which may have been utilized for energy expenditure instead of being stored.

Hepatic glycogen metabolism is controlled by the coordinated action of two enzymes, glycogen synthase and glycogen phosphorylase, both of which are regulated by phosphorylation and allosteric modulators [36]. It has been reported that STZ-induced diabetes produces a partial or total deficiency of insulin resulting in a decreased activity of glycogen synthase and an increase in the activity of glycogen phosphorylase [37] leading to decreasing tissue glycogen storage. Administration of AEG to diabetic rats restored the level of liver glycogen by decreasing glycogen phosphorylase activity and increasing glycogen synthase activity.

Effect of AEG on enzymatic and nonenzymatic antioxidant potential GSH, a chief intracellular redox component, functions as a direct free radical scavenger. GSH also facilitates the rearrangement of dicarbonyl to hydroxy acids and entraps reactive unsaturated aldehydes into nonreactive hydrophilic Michael addition that are easily excretable by the cell [38]. GSH also acts as a cosubstrate for GPx activity and cofactor for many enzymes. GSH is mainly involved in the synthesis of important macromolecules and in the protection against reactive oxygen species [39]. A marked decrease in hepatic GSH was observed in STZ-induced diabetic rats [40]. The decreased GSH content contributes to the pathogenesis associated with the chronic diabetic state. The present study showed a decreased content of GSH in hepatic tissue which significantly increased on AEG treatment.

SOD and CAT are two scavenging enzymes that remove the toxic free radicals [41]. In the enzymatic antioxidant defense system, SOD is one of the most important enzymes and scavenges $\mathrm{O}_{2}{ }^{-}$anion (which is the first product of $\mathrm{O}_{2}$ radical) to form $\mathrm{H}_{2} \mathrm{O}_{2}$ thus diminishing the toxic effects [42]. These enzyme activities were found to be inactivated by ROS in diabetic conditions [43]. In the present study, an increase in SOD, GPx, and GR activities in the hepatic tissues of diabetic rats were observed on treatment with AEG indicating that both could inhibit or reduce the oxidative stress in diabetes. Hyperglycemia was reported to generate reactive oxygen species that may alter the innate antioxidant mechanism by acting as an integral signaling molecule [44]. The present study showed significant elevation of hepatic TBARS content in diabetic rats suggesting that peroxidative injury may be involved in the development of diabetic complications. AEG was observed to significantly reduce the hepatic lipid peroxidation product levels in diabetic rats indicating that AEG is a potent inhibitor of oxidative damage of hepatic tissues. Further, to study the effect of AEG on insulin signaling markers, protein expressions were determined in skeletal muscle of HFD/STZ-treated Type-2 diabetic rats. The function of specific tissue and its role in skeletal muscle and adipocytes has been well elucidated [45]. Hence, skeletal muscle tissues were used for this study.

The immunoblotting followed by Western blot analysis, an upregulation in the expression of IR $\beta$, IRS1, PI3K, Akt/PKB, GLUT4, GSK3 $\beta$, and PPAR $\gamma$ was observed after treatment with AEG demonstrating its insulinomimetic action.

\section{CONCLUSION}

AEG isolated from the methanolic extract of $C$. fistula exerts its antidiabetic effect in HFD and low dose STZ-induced diabetic rats. The study shows that oral administration of AEG leads to a significant restoration of the blood glucose and carbohydrate metabolic enzyme such as hexokinase, G6P, F16BP, and increased glycogen synthase. AEG enhances the glycolytic enzymes and controls the glucose metabolism in the liver tissues of STZ-induced diabetic rats. The ameliorating potential of AEG by protecting specific tissues in diabetic rats suggests that AEG might play a significant role in alleviating the damages caused by oxidative stress. This investigation reveals the potential role of AEG for use as a natural oral agent, with both hypoglycemic and hypolipidemic effects. The study also demonstrates that AEG exhibits antidiabetic activity by stimulating insulin production from the pancreas and thus, could be an ideal drug candidate for the management of diabetes and its complications.

\section{REFERENCES}

1. Ford ES, Li C, Sattar N. Metabolic syndrome and incident diabetes: Current state of the evidence. Diabetes Care 2008;31(9):1898-904

2. de Sousa E, Zanatta L, Seifriz I, Creczynski-Pasa TB, Pizzolatti MG, Szpoganicz B, et al. Hypoglycemic effect and antioxidant potential of kaempferol-3,7-O-(alpha)-dirhamnoside from Bauhinia forficata leaves. J Nat Prod 2004;67(5):829-32.

3. Valiathan MS. Healing plants. Curr Sci 1998;75:1122-7.

4. Franconi F, Seghieri G, Canu S, Straface E, Campesi I, Malorni W. Are the available experimental models of Type 2 diabetes appropriate for a gender perspective? Pharmacol Res 2008;57(1):6-18.

5. Zhao S, Chu Y, Zhang C, Lin Y, Xu K, Yang P, et al. Diet-induced central obesity and insulin resistance in rabbits. J Anim Physiol Anim Nutr (Berl) 2008;92(1):105-11.

6. Szkudelski T. The mechanism of alloxan and streptozotocin action in B cells of the rat pancreas. Physiol Res 2001:50(6):537-46

7. Srinivasan K, Viswanad B, Asrat L, Kaul CL, Ramarao P. Combination of high-fat diet-fed and low-dose streptozotocin-treated rat: A model for Type 2 diabetes and pharmacological screening. Pharmacol Res 2005;52(4):313-20

8. Sahin K, Onderci M, Tuzcu M, Ustundag B, Cikim G, Ozercan IH, et al. Effect of chromium on carbohydrate and lipid metabolism in a rat model of Type 2 diabetes mellitus: The fat-fed, streptozotocin-treated rat. Metabolism 2007;56(9):1233-40.

9. Anand S, Muthusamy VS, Sujatha S, Sangeetha KN, Raja RB, Sudhagar S, et al. Aloe-emodin glycosides stimulates glucose transport and glycogen storage through PI3K dependent mechanism in L6 myotubes and inhibits adipocytes differentiation in 3T3 L1 adipocytes. FEBS Lett 2010;584:3170-8.

10. Brandstrup N, Kirk JE, Bruni C. Determination of hexokinase in tissues. J Gerentol 1957;12(2):166-71

11. Baginsky ES, Foa PP, Zad B. Glucose 6-phosphatase. In: Bergmeyer's Methods in Enzymatic Analysis. Vol. 2. New York, NY: Academic Press; 1974. p. 788-92.

12. Gancedo JM, Gancedo C. Fructose-1,6-diphosphatase, phosphofructokinase and glucose-6-phosphate dehydrogenase from fermenting and non fermenting yeasts. Arch Mikrobiol 1971;76(2):132-8.

13. Maiti R, Jana D, Das UK, Ghosh D. Antidiabetic effect of aqueous extract of seed of Tamarindus indica in streptozotocin-induced diabetic rats. J Ethnopharmacol 2004;92(1):85-91.

14. Kakkar P, Das B, Viswanathan PN. A modified spectrophotometric assay of superoxide dismutase. Indian J Biochem Biophys 1984;21(2):130-2.

15. Rotruck JT, Pope AL, Ganther HE, Swanson AB, Hafeman DG, Hoekstra WG. Selenium: Biochemical role as a component of 
glutathione peroxidase. Science 1973;179(4073):588-90

16. Moron MJ, Diperrie JW, Manner, KB. Levels of glutathione, glutathione reductase and glutathione-S-transferase by limited proteolysis. J Biol Chem 1979;260:577-89.

17. Sangeetha MS, Priyanga S, Hemmalakshmi S, Devaki K. In vivo antidiabetic potential of Cyclea peltata in streptozotocin induced diabetic rats. Asian J Pharm Clin Res 2015;8(1):103-8.

18. Nagasaki M, Nakai N, Oshida Y, Li Z, Xu M, Obayashi M, et al. Exercise training prevents maturation-induced decreases in insulin receptor substrate-1 and phosphatidylinositol 3-kinase in rat skeletal muscle. Metabolism 2000;49(7):954-9.

19. Srivastava AK, Mishra A, Gautam S, Pal S, Mishra A, Rawat AK, et al. Effect of Momordica charantia fruits on streptozotocin induced diabetes mellitus and its associated complications. Int J Pharm Pharm Sci 2015;7(3):356-63.

20. Qureshi SA, Ding V, Li Z, Szalkowski D, Biazzo-Ashnault DE, Xie D, et al. Activation of insulin signal transduction pathway and antidiabetic activity of small molecule insulin receptor activators. J Biol Chem 2000;275(47):36590-5.

21. Liu K, Xu L, Szalkowski D, Li Z, Ding V, Kwei G, et al. Discovery of a potent, highly selective, and orally efficacious small-molecule activator of the insulin receptor. J Med Chem 2000;43(19):3487-94.

22. Qin B, Nagasaki M, Ren M, Bajotto G, Oshida Y, Sato Y. Cinnamon extract (traditional herb) potentiates in vivo insulin regulated glucose utilization via enhancing insulin signaling in rats. Diabetes Res Clin Pract 2003;62(3):139-48.

23. Saleem R, Faizi S, Siddiqui BS, Ahmed M, Hussain SA, Qazi A, et al. Hypotensive effect of chemical constituents from Aloe barbadensis. Planta Med 2001;67(8):757-60.

24. Eisenbarth GS, Ziegler AG, Colman PA. Pathogenesis of insulin dependent (Type 1) diabetes mellitus. Philadelphia, PA: Lea Febiger; 1994. p. 216-39.

25. Sharma SR, Dwivedi SK, Swarup D. Hypoglycaemic, antihyperglycaemic and hypolipidemic activities of Caesalpinia bonducella seeds in rats. J Ethnopharmacol 1997;58(1):39-44.

26. Radhika R, Krishnakumari S, Sudarsanam D. Antidiabetic activity of Rheum emodi in alloxan induced diabetic rats. Int J Pharm Sci Res 2010;1(8):296-300.

27. Gupta BL, Nehal M, Baquer NZ. Effect of experimental diabetes on the activities of hexokinase, glucose-6-phosphate dehydrogenase and catecholamines in rat erythrocytes of different ages. Indian J Exp Biol 1997;35(7):792-5.

28. Murray RK, Granner DK, Mayes PA, Rodwell VW. Harper's Biochemistry. $25^{\text {th }}$ ed. Stanford, Connecticut: Appleton \& Lange; 2000. p. 610-7.

29. Grover JK, Vats V, Rathi SS. Anti-hyperglycemic effect of Eugenia jambolana and Tinospora cordifolia in experimental diabetes and their effects on key metabolic enzymes involved in carbohydrate metabolism.
J Ethnopharmacol 2000;73(3):461-70.

30. Berg JM, Tymoczko JL, Stryer L, editors. Glycolysis and gluconeogenesis. In: Biochemistry. New York: WH. Freeman and Company; 2001. p. 425-64

31. Saxena A, Bhatnagar M, Garg NK. Enzyme charges in rat tissue during hyperglycemia. Arogya J Health Sci 1984;10:33-7.

32. Vats V, Yadav SP, Grover JK. Ethanolic extract of Ocimum sanctum leaves partially attenuates streptozotocin-induced alterations in glycogen content and carbohydrate metabolism in rats. J Ethnopharmacol 2004;90(1):155-60.

33. Bollen M, Keppens S, Stalmans W. Specific features of glycogen metabolism in the liver. Biochem J 1998;336:19-31.

34. Gannon MC, Nuttall FQ. Effect of feeding, fasting, and diabetes on liver glycogen synthase activity, protein, and mRNA in rats. Diabetologia 1997;40(7):758-63.

35. Hikino H, Kobayashi M, Suzuki Y, Konno C. Mechanisms of hypoglycemic activity of aconitan A, a glycan from Aconitum carmichaeli roots. J Ethnopharmacol 1989;25(3):295-304.

36. Ferrer JC, Favre C, Gomis RR, Fernández-Novell JM, GarcíaRocha $\mathrm{M}$, de la Iglesia $\mathrm{N}$, et al. Control of glycogen deposition. FEBS Lett 2003;546(1):127-32.

37. Gayathri M, Kannabiran K. Antidiabetic and ameliorative potential of Ficus bengalensis bark extract in streptozotocin induced diabetic rats. Indian J Clin Biochem 2008;23(4):394-400.

38. Aldini G, Dalle-Donne I, Facino RM, Milzani A, Carini M. Intervention strategies to inhibit protein carbonylation by lipoxidation-derived reactive carbonyls. Med Res Rev 2007;27(6):817-68.

39. Burk RF. Glutathione dependent protection by rat liver microsomal protein against lipid peroxidation. Biochim Biophys Acta 1983;757(1):21-8.

40. Helen A, Vijayammal PL. Vitamin C supplementation on hepatic oxidative stress induced by cigarette smoke. J Appl Toxicol 1997;17(5):289-95

41. Wohaieb SA, Godin DV. Alterations in free radical tissue-defense mechanisms in streptozocin-induced diabetes in rat. Effects of insulin treatment. Diabetes 1987;36(9):1014-8.

42. Bhattacharya A, Chatterjee A, Ghosal S, Bhattacharya SK. Antioxidan activity of active tannoid principles of Emblica officinalis (amla). Indian J Exp Biol 1999;37(7):676-80.

43. Ahmed S, Rabman A, Alam A, Saleem M, Athar M, Sultana S Evaluation of the efficacy of Lawsonia alba in the alleviation of the CCl4 induced oxidative stress. J Ethnopharmacol 2000;69(2):57-164.

44. Anuradha CV, Ravikumar P. Restoration on tissue antioxidants by fenugreek seeds (Trigonella foenum Graecum) in alloxandiabetic rats. Ind J Physiol Pharmacol 2001;45(4):408-20.

45. Goldstein BJ. Protein-tyrosine phosphatases: Emerging targets for therapeutic intervention in Type 2 diabetes and related states of insulin resistance. J Clin Endocrinol Metab 2002;87(6):2474-80. 